\title{
Factors Contributing to the Students Academic Performance: A Case Study of Islamia University Sub- Campus
}

\author{
Shoukat Ali ${ }^{1}$, Zubair Haider ${ }^{2, *}$, Fahad Munir ${ }^{1}$, Hamid Khan ${ }^{1}$, Awais Ahmed ${ }^{3}$ \\ ${ }^{1}$ Lecturer, Department of Commerce, The Islamia University of Bahawalpur, RYK Campus, Pakistan \\ ${ }^{2}$ Lecturer, Department of Educational Training, the Islamia University of Bahawalpur, Pakistan \\ ${ }^{3}$ Research Scholar, Department of Commerce, IUB, RYK Campus, Pakistan \\ *Corresponding author: zubairiub@hotmail.com
}

Received June 22, 2013; Revised July 30, 2013; Accepted August 01, 2013

\begin{abstract}
The present research study was design to investigate the factors affecting academic performance of graduate students of Islamia University of Bahawalpur Rahim Yar Khan Campus. The variables under consideration were the academic performance (student's grades/marks) as a dependent variable and the gender, age, faculty of study, schooling, father/guardian social economic status, and residential area, medium of schooling; tuition trend, daily study hours and accommodation trend were independent variables. The data were collected from 100 students through separate structured questionnaire from different departments of Islamia University of Bahawalpur, Rahim Yar Khan Campus using the simple random sampling technique. For analysis, linear regression model, correlation analysis, and descriptive analysis were used. The findings revealed that age, father/guardian social economic status and daily study hours significantly contribute the academic performance of graduate students. A linear model was also proposed that will be helpful to improve the academic performance of graduate students at University level.
\end{abstract}

Keywords: academic performance, public sector, school education, medium of instruction

Cite This Article: Ali Shoukat, Zubair Haider, Hamid Khan and Awais Ahmed, "Factors Contributing to the Students Academic Performance: A Case Study of Islamia University Sub-Campus." American Journal of Educational Research 1, no. 8 (2013): 283-289. doi: 10.12691/education-1-8-3.

\section{Introduction}

Students academic gain and learning performance is affected by numerous factor including gender, age, teaching faculty, students schooling, father/guardian social economic status, residential area of students, medium of instructions in schools, tuition trend, daily study hour and accommodation as hostelries or day scholar. Many researchers conducted detailed studies about the factors contributing student performance at different study levels. Graetz (1995) suggested “A student educational success contingent heavily on social status of student's parents/ guardians in the society. Considine and Zappala (2002) noticed the same that parent's income or social status positively affects the student test score in examination. According to Minnesota (2007) "the higher education performance is depending upon the academic performance of graduate students. Durden and Ellis quoted Staffolani and Bratti, (2002) observed that "the measurement of students previous educational outcomes are the most important indicators of students future achievement, this refers that as the higher previous appearance, better the student's academic performance in future endeavours.

Lot of studies have been conducted in the area of students achievement and these studies identify and analyze the number of factors that affect the academic performance of the student at school, college and even at university level. Their finding identify students' effort, previous schooling, parent's educational background, family income, self motivation of students, age of student, learning preferences and entry qualification of students as important factors that have effect on student's academic performance in different setting. The utility of these studies lies in the need to undertake corrective measures that improve the academic performance of graduate students.

It is generally assumed that the students who showed better or higher performance in the starting classes of their studies also performed better in future academic years at degree level. Everyone can be surprised with this assumption if it could be proved scientifically. From the last two decades it has been noticed significantly that there is great addition in research literature and review material relating to indicators of academic achievement with much emphasis on this dialogue, whether traditional achievement measures of academic performance are best determinants of future academic gain at university or higher level or innovative measures. However, it is also observed that many of the researchers are not agree with this view point or statement. Reddy and Talcott (2006) looks disagree with these assumptions that future academic gains are resolute by preceding performance. In their research on the relationship between previous academic performance 
and subsequent achievement at university level, they found that students learning or studying at graduate level and the score secured did not predict any academic achievement at university level. They also cited Pearson and Johnson (1978) who observed that on the whole grade association of only 0.28 between graduate level marks and university degree achievement.

It is also confirmed in the study of Oregon State University (2003) on graduate admissions that normal measures of educational potential and academic performance such as high school GPA (Grade Point Average) scores showed only $30 \%$ of the deviation in initial or starting (first) year at college. It is important to note that even these studies do not agree with the former studies who explored that previous achievement affect the future performance of the students in studies, they confirmed that the admission scores are related to academic performance at university level but to a very minimal extent. McDonald et.al (2001) also suggested that the scores of graduate level studies still out perform any other single measure of cognitive aptitude in predicting success at university level.

Parent's socio-economic condition, which includes parents' academic and professional qualification, revenue and occupational affiliation, is also associated with academic gain of students. The results of many studies confirmed that academic achievement of students is contingent upon parent's socio-economic condition. So the students belonging from higher social economical backgrounds will perform better than other students associated with low social economic backgrounds. "Social and economical status of student is generally determined by combining parents' qualification, occupation and income standard” (Jeynes, 2002). Among many research studies conducted on academic achievement, it is not very surprising to observe that Socio-economic status is one of the main elements studied while predicting academic performance.

Graetz (1995) conducted a study on socio-economic status of the parents of students and concluded that the socio economic background has a great impact on student's academic performance, main source of educational imbalance among students and student's academic success contingent very strongly on parent's socio economic standard. Considine and Zappala (2002) also having the same views as Graetz (1995), in their study on the influence of social and economic disadvantage in the academic performance of school students noticed, where the parents or guardians have social, educational and economical advantage definitely strengthen the higher level success in future. But it is also noted that these parents make available sufficient psychological and emotional shore up to their children by providing good educational and learning environment that produce confidence and the improvement of skills needed for success.

On other hand Pedrosa et.al (2006) in their study on social and educational background pointed out those students who mostly come from deprived socio-economic and educational background performed relatively better than others coming from higher socio-economic and educational area. They named this phenomena educational elasticity. It is obvious and true that the criteria for categorizing socio-economic standard in different countries are different depending of their norms and values. The criteria for low socio-economic status for developed country will be different from the criteria of developing nations and same will be in the case of developing and under developing countries. "The total income of families, monthly or annually and their expenditures also put a great effect on the learning and academic opportunities accessible to youngsters and their chances of educational success. Furthermore, he also pointed that due to residential stratification and segregation, the students belonging to low-income backgrounds usually attend schools with lower funding levels, and this situation reduced achievement motivation of the students and high risk of educational malfunction in future life endeavors” (Escarce, 2003).

Considine \& Zappala (2002) observed that children comes from those families having low income make known more subsequent models in terms of learning outcomes; low literacy level, low retention rate, problems in school behaviour and more difficulty in their studies and mostly display negative attitude towards studies and school. The view point of Considine and Zappala is more strengthen by this statement of Eamon, According to Eamon (2005) "Those students usually come out from low socio-economic status or area show low performance in studies and obtained low scores as compared to the other students or their counter parts”.

It is also assumed that children learning outcome and educational performance are strongly affected by the standard and type of educational institution in which students get their education. The educational environment of the school one attends sets the parameters of students' learning outcomes. Considine and Zappala (2002) quoted Sparkles (1999) showed that schools environment and teachers expectations from their students also have strong influence on student performance. Most of the teachers working in poor schools or schools having run short of basic facilities often have low performance expectations from their students and when students know that their teachers have low performance expectations from them, hence it leads to poor performance by the students. Kwesiga (2002) approved that performance of the students is also influenced by the school in which they studied but he also said that number of facilities a school offers usually determine the quality of the school, which in turn affect the performance and accomplishment of its students. Sentamu (2003) argue that schools influence educational process in content organization, teacher and teaching learning and in the end evaluation of the all. All these educationists and researchers agreed with this principle that schools put strong effect on academic performance and educational attainment of students.

Students from elite schools are expected to perform good because they attend these elite schools and the main reason behind is that these schools are usually very rich in resources and facilities. Some researchers have the view that school ownership and the funds available in schools do indeed influenced the performance of the student. Crosne and Elder (2004) noticed that school ownership, provision of facilities and availability of resources in school is an important structural component of the school. Private schools due to the better funding, small sizes, serious ownership, motivated faculty and access to resources such as computers perform better than public schools. These additional funding resources and facilities 
found in private schools enhance academic performance and educational attainment of their students. It is also very pleasing that students from Govt schools colleges and universities in Punjab Pakistan are providing the laptops by the Punjab Government, so that the students could interact with the whole world and know about the latest developments and innovations.

It is concluded that the type of schools in which students studies greatly influence the educational performance and academic achievement of the students. Miller and Birch (2007) summarized the views of many researcher and educationist in their study on the influence of high school attended on university performance. This study let the research scholars to hypothesize that the background to the students positively correlates with the academic attainment of graduate students.

1. $\mathrm{H}=$ on average the academic performance of male and female student are equal.

2. $\mathrm{H}=$ on average the academic performance of graduate students with respect to their schooling perspectives or background (i.e. Government /Private) are equal.

3. $\mathrm{H}=$ on average the academic performance of graduate students with respect to their residential area (i.e. Urban /Rural) are equal.

4. $\mathrm{H}=$ on average the academic performance of graduate students with respect to their medium of instruction in school (i.e. English /Urdu) are equal.

5. $\mathrm{H}=$ on average the academic performance of graduate students with respect to their accommodation (i.e. Hostelries/Day Scholar) are equal.

\section{Research Methodology}

In this study a linear model of graduate student performance was designed. graduate student academic performance was taken as a dependent variable and gender, age, faculty of study, schooling, father/guardian social economic status, residential area, medium of schooling, tuition, study hour and accommodation as an independent variables. All graduates students in Islamia University of Bahawalpur Rahim Yar Khan Campus. The sample consist of $(n=100)$ graduate students of Islamia University of Bahawalpur Rahim Yar Khan Campus.

Simple random sampling technique was employed in the selecting the sample from the targeted population. The researcher personally went to the respondents and filled out the questionnaires so that the true responses could be obtained. The researcher use close ended questionnaires because the population is literate and large and time for collecting data is limited. Data from Questionnaires was compiled, sorted, edited, classified and coded into the coding sheet of SPSS 13.0 (version) and Microsoft Excel 2007.

The regression functions to fit the linear regression. For correlation analysis the correlation function built in Microsoft Excel 2007. For testing the hypothesis that the academic performance of graduate students of Islamia University of Bahawalpur Rahim Yar Khan Campus varies with gender using built in t-test function in SPSS. Graphs are constructed using Microsoft Excel 2007 graphical functions.

\section{Discussion and Results}

Table 1. Gender, School, Residential Area, Medium of Instructions, Tuition Trend and Accommodation Trend wise distribution of participants

\begin{tabular}{|c|c|c|c|c|c|}
\hline & & Frequency & Percent & Valid Percent & Cumulative Percent \\
\hline \multirow[t]{3}{*}{ Gender } & Male & 51 & 51 & 51 & 51 \\
\hline & Female & 49 & 49 & 49 & 100 \\
\hline & Total & 100 & 100 & 100 & 100 \\
\hline \multirow[t]{3}{*}{ School } & Private & 26 & 26 & 26 & 26 \\
\hline & Government & 74 & 74 & 74 & 100 \\
\hline & Total & 100 & 100 & 100 & 100 \\
\hline Residential & Rural & 16 & 16 & 16 & 16 \\
\hline \multirow[t]{2}{*}{ Area } & Urban & 84 & 84 & 84 & 100 \\
\hline & Total & 100 & 100 & 100 & 100 \\
\hline Medium of & English & 29 & 29 & 29 & 29 \\
\hline \multirow[t]{2}{*}{ Instruction } & Urdu & 71 & 71 & 71 & 100 \\
\hline & Total & 100 & 100 & 100 & 100 \\
\hline \multirow[t]{3}{*}{ Tuition Trend } & No & 90 & 90 & 90 & 90 \\
\hline & Yes & 10 & 10 & 10 & 100 \\
\hline & Total & 100 & 100 & 100 & 100 \\
\hline Accommodation & Hostel & 12 & 12 & 12 & 12 \\
\hline \multirow[t]{2}{*}{ Trend } & Days & 88 & 88 & 88 & 100 \\
\hline & Total & 100 & 100 & 100 & 100 \\
\hline \multicolumn{3}{|c|}{$\begin{array}{l}\text { The above Table showed that } 49 \% \text { graduates are female } \\
\text { and } 51 \% \text { graduate is male at Islamia University of } \\
\text { Bahawalpur Rahim Yar Khan Campus. The table } \\
\text { constructed to show the background schooling of graduate } \\
\text { students of Islamia University of Bahawalpur Rahim Yar }\end{array}$} & $\begin{array}{l}\text { Khan Campus. } \\
\text { schooling backgr } \\
\text { background from } \\
\text { The above in } \\
\text { students of Islam }\end{array}$ & $\begin{array}{l}\text { we observe } \\
\text { from privat } \\
\text { rnment. } \\
\text { ation showe } \\
\text { iiversity of B }\end{array}$ & $\begin{array}{l}26 \% \text { graduates } \\
\text { ad } 74 \% \text { schooling } \\
\text { at } 16 \% \text { graduate } \\
\text { walpur Rahim Ya }\end{array}$ \\
\hline
\end{tabular}


Khan Campus belong to rural area and $84 \%$ belong to urban area. The above table showed that $29 \%$ graduate students of Islamia University of Bahawalpur Rahim Yar Khan Campus done their forming schooling from English medium schools and $71 \%$ from Urdu medium schools. The table showed that $10 \%$ graduate students of Islamia
University of Bahawalpur Rahim Yar Khan Campus got Tuition and $90 \%$ do not get the tuition. The above information revealed that $12 \%$ graduate students of Islamia University of Bahawalpur Rahim Yar Khan Campus are hostelries and 88\% are day scholars.

\begin{tabular}{|c|c|c|c|c|c|c|c|c|}
\hline \multicolumn{2}{|c|}{ Regression Statistics } & & & & & & & \\
\hline Multiple R & 0.55897175 & & & & & & & \\
\hline R Square & $\begin{array}{c}0.31244941 \\
8\end{array}$ & & & & & & & \\
\hline $\begin{array}{c}\text { Adjusted R } \\
\text { Square }\end{array}$ & $\begin{array}{c}0.24369435 \\
9 \\
\end{array}$ & & & & & & & \\
\hline Standard Error & $\begin{array}{c}5.03234281 \\
5\end{array}$ & & & & & & & \\
\hline Observations & 100 & & & & & & & \\
\hline \multicolumn{9}{|l|}{ ANOVA } \\
\hline & $d f$ & SS & MS & $F$ & $\begin{array}{c}\text { Significance } \\
\mathrm{F}\end{array}$ & & & \\
\hline Regression & 9 & 1035.757321 & $\begin{array}{c}115.084146 \\
8\end{array}$ & 4.54438445 & 6.02346E-05 & & & \\
\hline Residual & 90 & 2279.202679 & $\begin{array}{c}25.3244742 \\
1\end{array}$ & & & & & \\
\hline \multirow[t]{2}{*}{ Total } & 99 & 3314.96 & & & & & & \\
\hline & Coefficients & $\begin{array}{c}\text { Standard } \\
\text { Error }\end{array}$ & T Stat & P-value & Lower 95\% & Upper 95\% & $\begin{array}{c}\text { Lower } \\
95.0 \% \\
\end{array}$ & $\begin{array}{l}\text { Upper } \\
95.0 \% \\
\end{array}$ \\
\hline Intercept & $\begin{array}{c}68.8777923 \\
2\end{array}$ & 7.73124752 & $\begin{array}{c}8.90901399 \\
1\end{array}$ & $\begin{array}{c}\text { 5.32367E- } \\
14\end{array}$ & 53.51832004 & 84.2372646 & $\begin{array}{c}53.5183200 \\
4\end{array}$ & 84.2372646 \\
\hline Female & $\begin{array}{c}- \\
0.89840221 \\
9\end{array}$ & 1.058273132 & $\begin{array}{c}- \\
0.84893227 \\
6\end{array}$ & $\begin{array}{c}0.39817138 \\
5\end{array}$ & -3.000846463 & $\begin{array}{c}1.20404202 \\
4\end{array}$ & $\begin{array}{c}- \\
3.00084646 \\
3\end{array}$ & $\begin{array}{c}1.20404202 \\
4\end{array}$ \\
\hline Age & $\begin{array}{c}- \\
0.67782464 \\
6\end{array}$ & 0.293293737 & $\begin{array}{c}2.31107780 \\
4\end{array}$ & $\begin{array}{c}0.02311298 \\
1\end{array}$ & -1.260503835 & $\begin{array}{c}- \\
0.09514545 \\
8\end{array}$ & $\begin{array}{c}- \\
1.26050383 \\
5\end{array}$ & $\begin{array}{c}- \\
0.09514545 \\
8\end{array}$ \\
\hline Govt & $\begin{array}{c}0.21851819 \\
1\end{array}$ & 1.433222601 & $\begin{array}{c}0.15246633 \\
1\end{array}$ & $\begin{array}{c}0.87916043 \\
3\end{array}$ & -2.628828599 & $\begin{array}{c}3.06586498 \\
2\end{array}$ & $\begin{array}{c}- \\
2.62882859 \\
9\end{array}$ & $\begin{array}{c}3.06586498 \\
2\end{array}$ \\
\hline Income & $\begin{array}{c}0.00011477 \\
3\end{array}$ & 3.85092E-05 & $\begin{array}{c}2.98039842 \\
7\end{array}$ & $\begin{array}{c}0.00370153 \\
1\end{array}$ & 3.82676E-05 & $\begin{array}{c}0.00019127 \\
8\end{array}$ & 3.82676E-05 & $\begin{array}{c}0.00019127 \\
8\end{array}$ \\
\hline Urban & $\begin{array}{c}- \\
0.73079343 \\
5\end{array}$ & 2.677971595 & -0.27289066 & $\begin{array}{c}0.78556244 \\
4\end{array}$ & -6.051051307 & $\begin{array}{c}4.58946443 \\
7\end{array}$ & $\begin{array}{c}- \\
6.05105130 \\
7\end{array}$ & $\begin{array}{c}4.58946443 \\
7\end{array}$ \\
\hline Urdu med & $\begin{array}{c}- \\
0.34651852 \\
8\end{array}$ & 1.336546371 & $\begin{array}{c}- \\
0.25926412 \\
7\end{array}$ & $\begin{array}{c}0.79602355 \\
5\end{array}$ & -3.001801117 & $\begin{array}{c}2.30876406 \\
1\end{array}$ & $\begin{array}{c}- \\
3.00180111 \\
7\end{array}$ & $\begin{array}{c}2.30876406 \\
1\end{array}$ \\
\hline Tuition & $\begin{array}{c}- \\
0.46979281 \\
2\end{array}$ & 1.8955836 & $\begin{array}{c}- \\
0.24783544 \\
8\end{array}$ & $\begin{array}{c}0.80482628 \\
9\end{array}$ & -4.235700407 & $\begin{array}{c}3.29611478 \\
4\end{array}$ & $\begin{array}{c}- \\
4.23570040 \\
7\end{array}$ & $\begin{array}{c}3.29611478 \\
4\end{array}$ \\
\hline Hour & $\begin{array}{c}2.66101083 \\
4\end{array}$ & 0.764161232 & $\begin{array}{c}3.48226359 \\
1\end{array}$ & $\begin{array}{c}0.00076942 \\
5\end{array}$ & 1.142871204 & $\begin{array}{c}4.17915046 \\
5\end{array}$ & $\begin{array}{c}1.14287120 \\
4\end{array}$ & $\begin{array}{c}4.17915046 \\
5\end{array}$ \\
\hline Day Scholar & $\begin{array}{c}0.64223404 \\
5\end{array}$ & 3.21164814 & $\begin{array}{c}0.19997023 \\
9\end{array}$ & $\begin{array}{c}0.84195500 \\
5\end{array}$ & -5.738265408 & $\begin{array}{c}7.02273349 \\
8\end{array}$ & $\begin{array}{c}- \\
5.73826540 \\
8\end{array}$ & $\begin{array}{c}7.02273349 \\
8\end{array}$ \\
\hline
\end{tabular}

The section 4.2 is the summary of the fitted or factors as constant. This coefficient is significant at $5 \%$ estimated linear regression model by the method of least square. We use the Microsoft Excel 2007 in determining the results. In the above summary academic performance is used as dependent variable and the gender, age, faculty of study, schooling, father/guardian social economic status, and residential area, medium of schooling, tuition, study hour and accommodation as independent variables. We have the following findings:

$\mathrm{R}^{2}=31 \%$ : This shows that $31 \%$ variations in academic performance due to the gender, age, faculty of study, schooling, father/guardian social economic status, residential area, medium of schooling, tuition, study hour and accommodation. The coefficients of Female (Gender) show that test score will decrease by -0.89 units if the graduate is female (Gender). This coefficient is insignificant at $5 \%$ level of significance. The coefficients of Age shows that a unit increases in Age cause of decrease in academic performance by -0.67 , holding other

level of significance.

The coefficients of Government (Medium of Schooling) shows that a unit increases in Government (Medium of Schooling) cause of increase in academic performance by 0.21 , holding other factors as constant. This coefficient is insignificant at $5 \%$ level of significance. The coefficients of Income shows that a unit increases in Income cause of increase in academic performance by 0.0001 , holding other factors as constant. This coefficient is significant at $5 \%$ level of significance. The coefficients of Urban (Residential Area) show that a unit increases in urban cause of decrease in academic performance by -0.73 , holding other factors as constant. This coefficient is insignificant at $5 \%$ level of significance.

The coefficients of Urdu Medium (Medium of Schooling) show that a unit increases in Urdu medium (Medium of Schooling) cause of decrease in academic performance by -0.34 , holding other factors as constant. 
This coefficient is insignificant at 5\% level of significance. The coefficients of Tuition show that a unit increases in Tuition cause of decrease in academic performance by 0.46 , holding other factors as constant. This coefficient is insignificant at 5\% level of significance. The coefficients of study hour show that a unit increases in study hour cause of increase in academic performance by 2.66, holding other factors as constant. This coefficient is significant at 5\% level of significance. The coefficients of Day Scholar (Accommodation) show that test score will increase by 0.64 units if the graduate is Day Scholar (Accommodation). This coefficient is insignificant at 5\% level of significance.

Table 3. Correlation Analysis of Academic Performance with Significant Independent Variable

\begin{tabular}{ccc}
\hline Age & Income & Hour \\
\hline-0.23201 & 0.375419 & 0.429975 \\
\hline
\end{tabular}

After checking the significance level of factors in section 4.2, we came to know that the age, parental income and study hour have significant role in improving the student performance of graduate student. In this section, we compute the strength of association between dependent and independent variables (age, parental income and study hour). The above table showed that test score and age have negative correlation. This is due to most of the student studying in Islamia University of Bahawalpur Rahim Yar Khan Campus started graduation late, because they already busy in carrying their job. The next one is income level of parent supporting their children. We observe that there is positive relationship between income and student performance (test score). This implies that the parents having high income cause of high test score. Study time is one of the most important factors affecting the student scores. The correlation strength among test score and study hour is positive and greater than the age and income factor.

Table 4. Students Academic Performance and Gender

\begin{tabular}{|c|c|c|c|c|c|c|c|c|c|c|}
\hline & & \multicolumn{2}{|c|}{$\begin{array}{c}\text { Levene's Test for } \\
\text { Equality of } \\
\text { Variances }\end{array}$} & \multicolumn{7}{|c|}{ t-test for Equality of Means } \\
\hline & & \multirow[t]{2}{*}{$\mathrm{F}$} & \multirow[t]{2}{*}{ Sig } & \multirow[t]{2}{*}{$\mathrm{t}$} & \multirow[t]{2}{*}{$\mathrm{df}$} & \multirow{2}{*}{$\begin{array}{l}\text { Sig. (2- } \\
\text { tailed) }\end{array}$} & \multirow{2}{*}{$\begin{array}{c}\text { Mean } \\
\text { Difference }\end{array}$} & \multirow{2}{*}{$\begin{array}{l}\text { Std. Error } \\
\text { Difference }\end{array}$} & \multicolumn{2}{|c|}{$\begin{array}{l}\text { 95\% Confidence Interval } \\
\text { of the Difference }\end{array}$} \\
\hline & & & & & & & & & Lower & Upper \\
\hline \multirow{2}{*}{$\begin{array}{l}\text { OBTAINED } \\
\text { SCORE }\end{array}$} & $\begin{array}{c}\text { Equal } \\
\text { variances } \\
\text { assumed }\end{array}$ & .314 & .577 & $\begin{array}{c}- \\
.292\end{array}$ & 98 & .771 & -.33934 & 1.16293 & -2.64714 & 1.96847 \\
\hline & $\begin{array}{c}\text { Equal } \\
\text { variances not } \\
\text { assumed }\end{array}$ & & & $\begin{array}{c}- \\
.292\end{array}$ & 97.997 & .771 & -.33934 & 1.16187 & -2.64502 & 1.96635 \\
\hline
\end{tabular}

Sig. (2-tailed) $=.771 \delta$

As the significant two tailed value (p-value) is greater than $5 \%$, so we do not reject the null hypothesis and conclude at statistically the performance of graduate student do not vary with gender either they are male or female.

\begin{tabular}{|c|c|c|c|c|c|c|c|c|c|c|}
\hline & & \multicolumn{2}{|c|}{$\begin{array}{c}\text { Levene's Test for } \\
\text { Equality of } \\
\text { Variances } \\
\end{array}$} & \multicolumn{7}{|c|}{ t-test for Equality of Means } \\
\hline & & \multirow[t]{2}{*}{$\mathrm{F}$} & \multirow[t]{2}{*}{ Sig } & \multirow[t]{2}{*}{$\mathrm{t}$} & \multirow[t]{2}{*}{ df } & \multirow{2}{*}{$\begin{array}{l}\text { Sig. (2- } \\
\text { tailed) }\end{array}$} & \multirow{2}{*}{$\begin{array}{c}\text { Mean } \\
\text { Difference }\end{array}$} & \multirow{2}{*}{$\begin{array}{l}\text { Std. Error } \\
\text { Difference }\end{array}$} & \multicolumn{2}{|c|}{$\begin{array}{c}\text { 95\% Confidence Interval } \\
\text { of the Difference }\end{array}$} \\
\hline & & & & & & & & & Lower & Upper \\
\hline \multirow{2}{*}{$\begin{array}{l}\text { OBTAINED } \\
\text { SCORE }\end{array}$} & $\begin{array}{c}\text { Equal } \\
\text { variances } \\
\text { assumed } \\
\end{array}$ & 3.520 & .064 & 2.358 & 98 & .020 & 3.04158 & 1.28985 & .48191 & 5.60125 \\
\hline & $\begin{array}{c}\text { Equal } \\
\text { variances not } \\
\text { assumed }\end{array}$ & & & 2.793 & 62.990 & .007 & 3.04158 & 1.08895 & .86549 & 5.21767 \\
\hline
\end{tabular}

Sig. (2-tailed) $=.020 \delta$

As the significant two tailed value ( $\mathrm{p}$-value) is less than $5 \%$, so we reject the null hypothesis and conclude at statistically the performance of graduate student vary with schooling perspectives as if they belong to private or government schools. So it may be said that schooling whether it is private school or government school it definitely put effect on student's performance.

Table 6. Students Academic Performance and Residential Area

\begin{tabular}{|c|c|c|c|c|c|c|c|c|c|c|}
\hline & & \multicolumn{2}{|c|}{$\begin{array}{c}\text { Levene's Test for } \\
\text { Equality of } \\
\text { Variances }\end{array}$} & \multicolumn{7}{|c|}{ t-test for Equality of Means } \\
\hline & & \multirow{2}{*}{ F } & \multirow{2}{*}{ Sig } & \multirow{2}{*}{$\mathrm{t}$} & \multirow{2}{*}{ df } & \multirow{2}{*}{$\begin{array}{l}\text { Sig. (2- } \\
\text { tailed) }\end{array}$} & \multirow{2}{*}{$\begin{array}{c}\text { Mean } \\
\text { Difference }\end{array}$} & \multirow{2}{*}{$\begin{array}{l}\text { Std. Error } \\
\text { Difference }\end{array}$} & \multicolumn{2}{|c|}{$\begin{array}{l}\text { 95\% Confidence Interval } \\
\text { of the Difference }\end{array}$} \\
\hline & & & & & & & & & Lower & Upper \\
\hline \multirow{2}{*}{$\begin{array}{l}\text { OBTAINED } \\
\text { SCORE }\end{array}$} & $\begin{array}{c}\text { Equal } \\
\text { variances } \\
\text { assumed } \\
\end{array}$ & 1.805 & 182 & .862 & 98 & .391 & 1.36310 & 1.58046 & -1.77328 & 4.49947 \\
\hline & $\begin{array}{c}\text { Equal } \\
\text { variances not } \\
\text { assumed }\end{array}$ & & & 1.090 & 27.925 & .285 & 1.36310 & 1.25108 & -1.19994 & 3.92613 \\
\hline
\end{tabular}


As the significant two tailed value (p-value) is greater than $5 \%$, so we do not reject the null hypothesis and conclude at statistically the performance of graduate student do not vary with residential area. In residential area urban and rural areas were taken, so it obvious that living areas have no significant impact on students performance.

Table 7. Students Academic Performance and Medium of Instruction

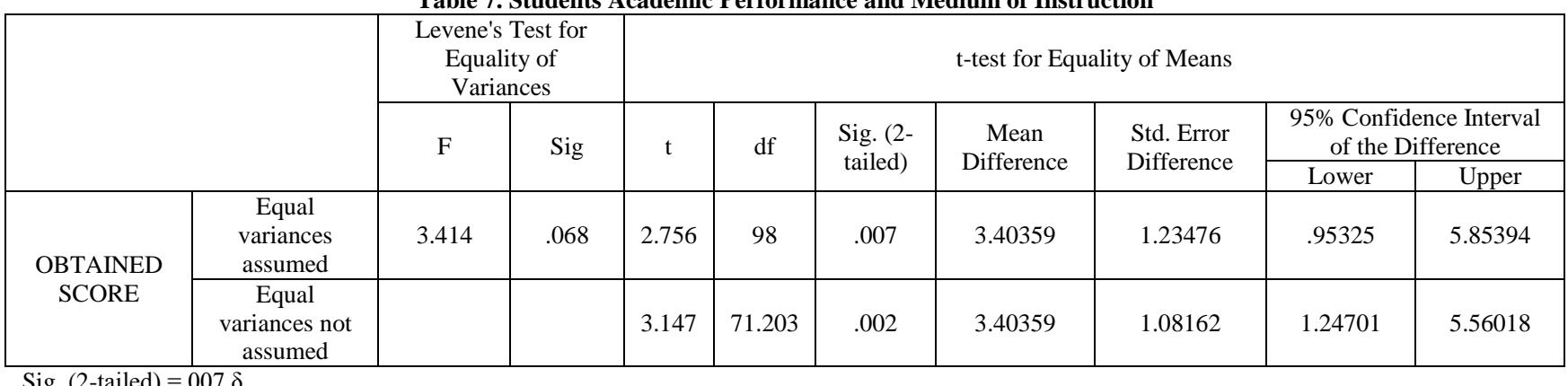

Sig. (2-tailed) $=.007 \delta$

As the significant two tailed value (p-value) is less than $5 \%$, so we reject the null hypothesis and conclude at statistically the performance of graduate student vary with

Table 8. Students Acac

medium of instructions. It means that in which language the teacher is teaching the students and what language he or she is using to communicate with the students.

or she is using to communition

\begin{tabular}{|c|c|c|c|c|c|c|c|c|c|c|}
\hline & & \multicolumn{2}{|c|}{$\begin{array}{c}\text { Levene's Test for } \\
\text { Equality of } \\
\text { Variances } \\
\end{array}$} & \multicolumn{7}{|c|}{ t-test for Equality of Means } \\
\hline & & \multirow[t]{2}{*}{$\mathrm{F}$} & \multirow[t]{2}{*}{ Sig } & \multirow[t]{2}{*}{$\mathrm{t}$} & \multirow[t]{2}{*}{ df } & \multirow{2}{*}{$\begin{array}{l}\text { Sig. (2- } \\
\text { tailed) }\end{array}$} & \multirow{2}{*}{$\begin{array}{c}\text { Mean } \\
\text { Difference }\end{array}$} & \multirow{2}{*}{$\begin{array}{l}\text { Std. Error } \\
\text { Difference }\end{array}$} & \multicolumn{2}{|c|}{$\begin{array}{c}\text { 95\% Confidence Interval } \\
\text { of the Difference }\end{array}$} \\
\hline & & & & & & & & & Lower & Upper \\
\hline \multirow{2}{*}{$\begin{array}{l}\text { OBTAINED } \\
\text { SCORE }\end{array}$} & $\begin{array}{c}\text { Equal } \\
\text { variances } \\
\text { assumed } \\
\end{array}$ & 4.321 & .040 & 1.566 & 98 & .120 & 2.76894 & 1.76777 & -.73913 & 6.27701 \\
\hline & $\begin{array}{c}\text { Equal } \\
\text { variances not } \\
\text { assumed }\end{array}$ & & & 2.572 & 25.350 & .016 & 2.76894 & 1.07650 & .55339 & 4.98449 \\
\hline
\end{tabular}

Sig. (2-tailed) $=.120 \delta$

As the significant two tailed value (p-value) is greater than 5\%, so we do not reject the null hypothesis and conclude at statistically the performance of graduate student do not vary with accommodation either they are living in hostel or living at their homes. Hostel life might be beneficial that it provide environment or peer study group but in results its effect is not significant on student's performance.

\section{Conclusion}

The descriptive analysis shows that $49 \%$ are female and $51 \%$ are male graduate students of Islamia University of Bahawalpur Rahim Yar Khan Campus. 26\% graduate students of Islamia University of Bahawalpur Rahim Yar Khan Campus schooling background from private sector and $74 \%$ from government sector. $16 \%$ graduate students of Islamia University of Bahawalpur Rahim Yar Khan Campus belong to rural area and $84 \%$ belong to urban area. 29\% graduate students of Islamia University of Bahawalpur Rahim Yar Khan Campus done their forming schooling from English medium schools and $71 \%$ from Urdu medium schools. 10\% graduate students of Islamia University of Bahawalpur Rahim Yar Khan Campus got tuition and $90 \%$ do not get tuition. $12 \%$ graduate students of Islamia University of Bahawalpur Rahim Yar Khan Campus are hostelries and $88 \%$ are day scholar.

For the regression analysis we use Microsoft Excel 2007. We took student academic performance (Test Score) as a dependent variable and gender, age, faculty of study, schooling, father/guardian social economic status, residential area, medium of schooling, tuition, study hour and accommodation as independent variables. After fitting the model (see, section 4.2) we conclude that the age, income and hour are statistically significant. This thing revealed that the university or government should take into account the following factors (age, income and hour). The impact of other factors may also on academic performance (Test Score) but it is not strongly significant therefore we should exclude from model.

The correlation analysis shows the age, income and hour have significant role in improving the student performance of graduate student. We compute the strength of association between dependent and independent variables (age, income and hour). The results show that (see, section 4.3) the test score and age have negative correlation. This is due to most of the student studying in Islamia University of Bahawalpur Rahim Yar Khan Campus started graduation late, because they already busy in carrying their job. The next one is income level of parent supporting their children. We observe that there is positive relationship between income and student performance (test score). This implies that the parents having high income cause of high test score. Study time is one of the most important factors affecting the student scores. The correlation strength among test score and study hour is positive and greater than the age and income factor. In short we rank the association level of different independent variable with academic performance as follow: age on 1st position, income on $2^{\text {nd }}$ position and hour on $3{ }^{\text {rd }}$ position respectively.

We test the hypothesis that the academic performance of graduate students of Islamia University of Bahawalpur Rahim Yar Khan Campus varies with gender, schooling, and residential area, medium of schooling and accommodation as follows;

We state our hypothesis as:

$H_{0}=$ on average the academic performance of graduate student with respect to gender (i.e. Male/Female), schooling (i.e. Government /Private), residential area (i.e. 
Urban /Rural), medium of instruction (i.e. English /Urdu) and accommodation (i.e. Hostelries /Day Scholar) are equal.

$H_{1}=$ on average the academic performance of graduate student with respect to gender (i.e. Male/Female), schooling (i.e. Government /Private), residential area (i.e. Urban /Rural), medium of schooling (i.e. English /Urdu) and accommodation (i.e. Hostelries /Day Scholar) are not equal.

As the significant two tailed values ( $\mathrm{p}$-values $=0.771$, $=0.391$ and $=0.12$ ) is greater than $5 \%$, so we do not reject the null hypothesis and conclude at statistically the performance of graduate student do not vary with gender, residential area and accommodation. As the significant two tailed values ( $p$-values $=0.02$ and $=0.007$ ) is less than $5 \%$, so we reject the null hypothesis and conclude at statistically the performance of graduate student vary with schooling and medium of schooling.

\section{Recommendation}

Because this study only for Islamia University of Bahawalpur Rahim Yar Khan Campus. Therefore its results may or may not be external valid. We recommend that this study should be conducted at a wide level of Pakistan, so that its result became valid for whole country.

\section{References}

[1] Bratti, M. and Staffolani, S. 2002, 'Student Time Allocation and Educational Production Functions', University of Ancona Department of Economics Working Paper No. 170.

[2] Considine, G. \& Zappala, G. (2002). Influence of social and economic disadvantage in the academic performance of school students in Australia. Journal of Sociology, 38, 129-148.

[3] Crosnoe, R., Monica, K. J and Glen, H .E .Jr. (2004). School size and the interpersonal side of education: An example of Race/Ethnicity and organizational context. Social Science Quarterly, 85(5).

[4] Durden, G. C. and Ellis, L. V. (1995). The effect of attendance on student learning in Principles of Economics. American Economic Review, 85, 343-346.
[5] Eamon, M.K (2005). Social demographic, school, neighborhood, and parenting influences on academic achievement of Latino young adolescents. Journal of Youth and Adolescence, 34(2), 163175.

[6] Escarce, J. J (2003). Socioeconomic status and the fates of adolescents. Retrieved on September 272007 from http://www.pubmedcentral.nih.gov/articlerender.fcgi?artid.

[7] Graetz, B. (1995), Socio-economic status in education research and policy in John Ainley et al., Socio-economic Status and School Education DEET/ACER Canberra.

[8] Jeynes, William H. (2002). Examining the effects of parental absence on the academic achievement of adolescents: the challenge of controlling for family income. Journal of family and Economic Issues 23(2).

[9] Kwesiga, C.J. (2002). Women's access to higher education in Africa: Uganda's experience. Kampala: Fountain publishers Ltd.

[10] McDonald, A.S, Newton, P.E, Whetton, Cand Benefield, P. (2001) Aptitude testing for university entrance: a literature review. National foundation for educational research.

[11] Minnesota Measures (2007) Report on higher education performance. Retrieved on May 24, 2008 from www.opencongress.org/bill/110.s/642/show-139k.

[12] Miller, W.P and Birch, R.E. (2007). The influence of type of high school attended on university performance. Retrieved on December 3, 2008.

from http://www3.interscience.wiley.com/journal/118538313.

[13] Oregon State University (2003). Graduate admissions policy proposal. Retrieved November 23, 2006 From http://eepm.orst.edu/dept/senate/committees/aac/agen/reports/2003 0115.html.

[14] Pearson, P. D., \& Johnson. (1978). Teaching reading comprehension. New York: Holt, Rinehart \& Winston.

[15] Pedrosa, et al (2006). Educational and social economic background of graduates and academic performance: consequences for affirmative action programs at a Brazilian research university. Retrieved on September 9, 2007. From: http://www.comvest.unicamp.br/paals/artigo2.pdf.

[16] Reddy, P and Talcott, J. (2006). Predicting university success in psychology: Are subject-specific skills important? Retrieved on July 4, 2008.

from http://www.aston.ac.uk/downloads/ihs/peelea/huw2006p.pdf.

[17] Sentamu, N.P. (2003). School's influence of learning: A case of upper primary schools in Kampala \& Wakiso Districts.

[18] Sparkes, J. (1999), Schools, Education and Social Exclusion, CASE Paper 29, Centre for Analysis of Social Exclusion, London School of Economics, London. 